\title{
Saline water, nitrogen and phosphorus on water relations and physiological aspects of West Indian cherry
}

\author{
Francisco Vanies da Silva Sá1*, Hans Raj Gheyi², Geovani Soares de Lima³, \\ Emanoela Pereira de Paiva', Claudivan Feitosa Lacerda ${ }^{4}$, Pedro Dantas Fernandes ${ }^{5}$
}

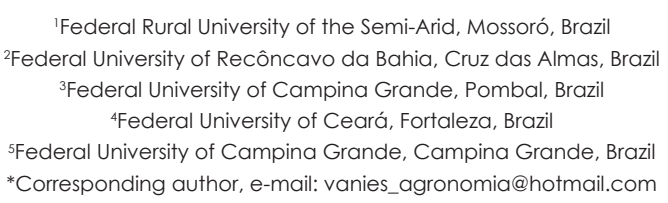

\begin{abstract}
Salinity is a common problem in arid and semi-arid regions, causing great damage to crop yields, and management strategies that reduce the effects of salt stress on plants are necessary. So, the aim of this study was to evaluate the interaction between salinity, nitrogen and phosphorus on water relations, gas exchange and chloroplastidic pigments of the West Indian cherry in the vegetative/reproductive phase transition. The cultivation was carried out in a greenhouse, in lysimeters filled with an Entisol of low phosphorus content. The experiment was arranged in a randomized complete block design, arranged in a factorial scheme with two factors, being five levels of electrical conductivity of irrigation water (ECW) $\left(0.6,1.4,2.2,3.0\right.$ and $\left.3.8 \mathrm{dS} \mathrm{m}^{-1}\right)$ and four P:N rates (100:100, 140:100, 100:140 and 140:140\% of recommendation) with three replications and one plant per plot. The analysis of results indicated that the seedlings of West Indian cherry cultivar BRS 366-Jaburu, grafted on the Criolo rootstock from the EMBRAPA Agroindústria Tropical

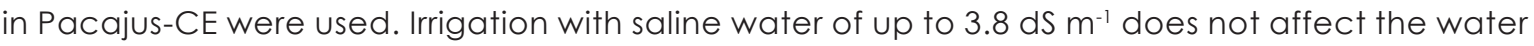
status of the West Indian cherry. Increased salinity of irrigation water reduces gaseous exchange activity and increases the percentage of leaf cell damage in the West Indian cherry. The $40 \%$ increase over recommended level in nitrogen supply increases the synthesis of chlorophyll b and carotenoids in the West Indian cherry, when irrigated with saline water of up to $2.2 \mathrm{dS} \mathrm{m}^{-1}$.
\end{abstract}

Keywords: Malphigia emarginata, chlorophyll fluorescence, saline stress, soil fertility

\section{Introduction}

The West Indian cherry (Malpighia emarginata DC.) is a fruit crop highly adaptable to the most diverse climates. Its commercial cultivation concentrates in the tropical and subtropical regions (Adriano et al., 2011). In Brazil, the crop is diffused in Northeast, North, South and Southeast regions. Nevertheless, the Northeast region is the primary producer with highlights to the semi-arid regions of Bahia, Ceará, Paraíba and Pernambuco (Adriano et al., 2011; Esashika et al., 2013).

Water shortages are characteristic of the Brazilian semiarid region, due to irregular distribution of rainfall, transforming irrigation a necessary strategy to maintain an acceptable level for crop yields in the area (Medeiros et al., 2003). However, inappropriate use of irrigation can salinize soils, causing economic and environmental impacts on agricultural lands (Sousa et al., 2012).

In general, soil salinization occurs due to the accumulation of soluble salts in the root zone, mainly the $\mathrm{Na}^{+}, \mathrm{Ca}^{2+}$ and $\mathrm{Mg}^{2+}$ cations and the $\mathrm{Cl}^{-}$and $\mathrm{SO}_{4}{ }^{2-}$ anions, but in the Brazilian semiarid soils, together with the salinity problems, it has been observed frequent sodicity issues, which occurs by excessive accumulation of sodium salts (Mesquita et al., 2015). The increase of the soluble salts content reduces the growth and 
productivity of several plant species mainly due to the osmotic effect and specific ion toxicity (Lacerda et al., 2006; Esteves \& Suzuki, 2008; Munns \& Tester, 2008).

In addition to the salinity problems, the soils of the Northeast region of the country still face issues regarding natural fertility, such as the low levels of phosphorus and nitrogen that have limited crop yields (Souza et al., 2009). Phosphorus is one of the most critical nutrient for cellular activity since it is an integral part of energy-rich molecules and the structure of nucleic acids themselves so that their low availability limits the development of crops since the initial stage (Epstein \& Bloom, 2006).

Nitrogen, in turn, is the most required nutrient by the plant to perform structural function and is part of several organic compounds vital to the plant, such as low molecular weight nitrogen compounds (amino acids, glycine, proline, oligosaccharides, etc.), in the osmotic adjustment of the plants under salinity conditions (Esteves \& Suzuki, 2008). Thus, nitrogen and phosphate fertilization shall attenuate the adverse effects of salinity on the plants, allowing the sustainable use of brackish water, thus guaranteeing agricultural production (Lacerda et al., 2006; Sousa et al., 2012; Ribeiro et al. al., 2016).

The objective of this study was to evaluate the interaction between salinity of irrigation water associated with nitrogen and phosphate fertilization on water relations, gas exchange and chloroplastidic pigments of the West Indian cherry.

\section{Materials and Methods}

The experiment carried out from June to December 2016, in a greenhouse at the Center of Technology and Natural Resources (CTRN) of the Federal University of Campina Grande (UFCG), located in the city of Campina Grande, Paraíba, Brazil, at the geographic coordinates $7^{\circ} 15^{\prime} 18^{\prime \prime}$ South latitude, 3552'28" West longitude and average altitude of $550 \mathrm{~m}$.

The experiment was installed in a randomized block with treatments arranged in a 5 $x 4$ factorial, relating to the electrical conductivity of irrigation water - ECW $(0.6 ; 1.4 ; 2.2 ; 3.0$ and $3,8 \mathrm{dS}^{-1}$ ) usually observed in the reservoirs of the Brazilian semi-arid region (MEDEIROS et al., 2003). Four percentage proportions of phosphorus and nitrogen P/N (100:100, 140:100, 100:140 and 140:1 140\% of recommendation) were applied, with three replicates of one plant per plot., respectively. The application of $100 \%$ of phosphate fertilization ( $45.0 \mathrm{~g}$ of $\mathrm{P}_{2} \mathrm{O}_{5}$ plant $^{-1}$ year ${ }^{-1}$ ) and nitrogen (23.85 $\mathrm{g}$ o $\mathrm{N} \mathrm{plant}^{-1}$ year-1) based on recommendations of Musser (1955).

The soil material used to fill the lysimeters was an Entisol of loamy clay texture (depth of 0-30 cm), coming from the municipality of Esperança - PB. The chemical and physical attributes of the soil were determined according to the methodologies contained in EMBRAPA (2009) and are shown in Table 1.

The West Indian cherry plants were grown in lysimeters, filled with $235 \mathrm{~kg}$ of soil, each lysimeter had two $18 \mathrm{~mm}$ equally spaced drains at the bottom. Above each drain, a geotextile cloth (Bidin type) and a layer of $0.50 \mathrm{~kg}$ of gravel were placed. The drainage water was collected using two PET bottles per lysimeter, with a capacity of $2 \mathrm{~L}$ each placed below the lysimeters, the drainage value being computed and used in the water balance of the crop.

Table 1. Chemical and physical characteristics of the soil used in the experiment.

\begin{tabular}{|c|c|c|c|c|c|c|c|c|c|}
\hline \multicolumn{10}{|c|}{ Chemical Characteristics } \\
\hline \multirow{2}{*}{$\begin{array}{c}\mathrm{pH}\left(\mathrm{H}_{2} \mathrm{O}\right) \\
(1: 2.5)\end{array}$} & \multirow{2}{*}{$\begin{array}{c}\text { O.M. } \\
\left(\text { dag kg }^{-1}\right)\end{array}$} & \multirow{2}{*}{$\begin{array}{c}\mathrm{P} \\
\left(\mathrm{mg} \mathrm{kg}^{-1}\right)\end{array}$} & $\mathrm{K}^{+}$ & $\mathrm{Na}^{+}$ & $\mathrm{Ca}^{2+}$ & $\mathrm{Mg}^{2+}$ & $\mathrm{H}^{+}+\mathrm{Al}^{3+}$ & ESP & \multirow{2}{*}{$\begin{array}{l}\text { ECse } \\
\left(\mathrm{dS} \mathrm{m}^{-1}\right)\end{array}$} \\
\hline & & & \multicolumn{5}{|c|}{ 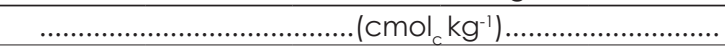 } & $\%$ & \\
\hline 5.63 & 1.830 & 18.20 & 0.21 & 0.17 & 3.49 & 2.99 & 5.81 & 1.34 & 0.61 \\
\hline \multicolumn{10}{|c|}{ Physical characteristics } \\
\hline \multicolumn{3}{|c|}{$\begin{array}{c}\text { Granulometric fraction } \\
\left(\mathrm{g} \mathrm{kg}^{-1}\right)\end{array}$} & \multirow{2}{*}{$\begin{array}{l}\text { Textural } \\
\text { class }\end{array}$} & \multicolumn{2}{|c|}{ Water content (kPa) } & \multirow[t]{2}{*}{ AW } & \multirow{2}{*}{$\begin{array}{c}\text { Total } \\
\text { porosity } \\
\mathrm{m}^{3} \mathrm{~m}^{-3}\end{array}$} & Ds & Dp \\
\hline Sand & Silt & Clay & & 33.42 & $\begin{array}{c}1519.5 \\
\text { dag } \mathrm{kg}^{-1}\end{array}$ & & & \multicolumn{2}{|c|}{-----(kg dm $\left.{ }^{-3}\right)^{----}$} \\
\hline 573 & 101 & 326 & LC & 12.68 & 4.98 & 7.70 & 0.5735 & 1.13 & 2.65 \\
\hline 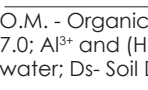 & $\begin{array}{l}\text { matter: Humi } \\
+\mathrm{Al}^{3+} \text { ) extrac } \\
\text { ensity; Dp- D }\end{array}$ & $\begin{array}{l}\text { Digestion W } \\
\text { ed using } 0.5 \downarrow \\
\text { nsity of parti }\end{array}$ & $\begin{array}{l}\text { ey-Black; Cc } \\
\text { aOAc PH } 7 \text {. }\end{array}$ & $\begin{array}{l}\text { and } \mathrm{Mg}^{2+} \mathrm{ex} \\
\text { ECse-Electr }\end{array}$ & $\begin{array}{l}\text { cted with } \mathrm{KC} \\
\text { I conductivity }\end{array}$ & $\begin{array}{l}\text { M pH 7.0; } \\
\text { il saturati }\end{array}$ & $\begin{array}{l}\text { and } K^{+} \text {extro } \\
\text { xtract; } L C-1\end{array}$ & $\begin{array}{l}\text { ed using } \\
\text { amy Clay }\end{array}$ & $\begin{array}{l}\mathrm{H}_{4} \mathrm{OAC} 1 \mathrm{Mp} \\
\mathrm{W} \text { - Availab }\end{array}$ \\
\hline
\end{tabular}


In the experiment, seedlings of BRS 366-Jaburu cultivar of West Indian cherry crop were grafted on the Criolo rootstock, from the EMBRAPA Agroindústria Tropical Seed Garden in Pacajus - CE. The grafted seedlings were acquired at the age of 240 days (150 days after sowing rootstock +90 days after grafting) and during the period were irrigated with low salinity water $\left(E C W=0.6 \mathrm{dS} \mathrm{m}^{-1}\right.$ ), being transplanted to lysimeters. After the transplant, the seedlings were acclimated for 30 days before the application of the salinity treatments.

The water with the lowest electrical conductivity (ECW) $\left(0.6\right.$ and $1.4 \mathrm{dS} \mathrm{m}^{-1}$ ) were obtained by the dilution of municipal supply water $\left(E C W=1.78 \mathrm{dS} \mathrm{m}^{-1}\right)$ with rainwater $(0.04$ $\mathrm{dS} \mathrm{m}^{-1}$ ), and the others with ECW equal to 2.2; 3.0 and $3.8 \mathrm{dS} \mathrm{m}^{-1}$ were prepared by addition of $\mathrm{NaCl}, \mathrm{CaCl}_{2} \cdot 2 \mathrm{H}_{2} \mathrm{O}$ and $\mathrm{MgCl}_{2} \cdot 6 \mathrm{H}_{2} \mathrm{O}$ salts to the supply water in the equivalent ratio of 7:2:1 between $\mathrm{Na}, \mathrm{Ca}$ and $\mathrm{Mg}$ ions, respectively. This relationship represents the average composition of the ion contents present in the waters used for irrigation in the semi-arid region of the Brazilian Northeast (MEDEIROS et al., 2003).

Irrigation with the different levels of water electrical conductivity was carried out by adopting the three-day irrigation shift, applying to each lysimeter a volume of water to maintain soil moisture close to its ideal retention capacity of water in the soil (33.42 kPa). In each irrigation, the amount of water was determined to meet the water requirement of the plant was determined using a water balance in the root zone obtained by the difference between the volume applied and the drainage, calculated every 30 days. A leaching fraction of 0.10 was administered every 30 days to avoid excessive accumulation of salts in the root zone (AYERS \& WESTCOT, 1999).

The $\mathrm{P}$ and $\mathrm{N}$ fertilization were performed according to the previously established treatments, using simple superphosphate $\left(18 \% \mathrm{P}_{2} \mathrm{O}_{5}, 18 \% \mathrm{Ca}^{2+}, 12 \% \mathrm{~S}\right)$ as a source of phosphorus and urea $(45 \% \mathrm{~N})$ as the source of nitrogen, based on the recommendation of Musser (1995); with the addition of $19.8 \mathrm{~g} \mathrm{~K}_{2} \mathrm{O}$ plant $^{-1}$ year $^{-1}$ using potassium chloride $\left(60 \% \mathrm{~K}_{2} \mathrm{O}\right)$. Concerning fertilization, 250 and $350 \mathrm{~g}$ of single superphosphate were used in the treatments at 100 and $140 \%$ of $P$, respectively. Nitrogen fertilization was divided into 24 equal parts, applied at 15-day intervals during the year, using $2.21 \mathrm{~g}$ of urea per plant in the treatment of $100 \%$ and $3.09 \mathrm{~g}$ of urea per plant in the treatment of $140 \%$ both diluted in $100 \mathrm{~mL}$ of rainwater 10.04 $\mathrm{dS} \mathrm{m}^{-1}$ ). Potassium fertilization was divided into 12 equal applications during the year, and 2.75 $\mathrm{g}$ of $\mathrm{KCl}$ per plant diluted in $100 \mathrm{~mL}$ of rainwater (ECW $=0.04 \mathrm{dS} \mathrm{m}^{-1}$ ) was supplied monthly. The management of fertilization ( $N$ and $P$ ) was initiated concomitantly with the transplanting of the seedlings to the lysimeters.

During the experiment, cultural and phytosanitary treatments recommended for the crop were conducted by monitoring the appearance of pests and diseases, adopting control measures when necessary.

The gaseous exchange were determined in the third leaf counted from apex, at 150 days post application of the salinity levels, using the portable tool of photosynthesis measurement "LCPro+" of ADC BioScientific Ltd., operating with irradiation $1200 \mu \mathrm{mol}$ photons $\mathrm{m}^{-2} \mathrm{~s}^{-1}$ and air flow of $200 \mathrm{~mL} \mathrm{~min}^{-1}$, and $\mathrm{CO}_{2}$ from the environment at the height of $3 \mathrm{~m}$ from the soil surface, obtaining the following variables: $\mathrm{CO}_{2}$ assimilation rate (A) ( $\left.\mu \mathrm{mol} \mathrm{m} \mathrm{m}^{-2} \mathrm{~s}^{-1}\right)$, transpiration (E) $\left(\mathrm{mol} \mathrm{H}_{2} \mathrm{O} \mathrm{m}^{-2} \mathrm{~s}^{-1}\right)$, stomatal conductance (gs) ( $\left.m o l \mathrm{H}_{2} \mathrm{O} \mathrm{m}^{-2} \mathrm{~s}^{-1}\right)$ and internal $\mathrm{CO}_{2}$ concentration. With these data in hands, the instantaneous water efficiency (WiUE) (A/E) $\left[\left(\mu \mathrm{mol} \mathrm{m} \mathrm{m}^{-2} \mathrm{~s}^{-1}\right) /\left(\mathrm{mol} \mathrm{H}_{2} \mathrm{O} \mathrm{m}^{-2} \mathrm{~s}^{-1}\right)^{-1}\right]$ and the instantaneous efficiency of the carboxylation (A) Ci) (EiCi) were quantified (Silva et al., 2014).

Immediately after the gaseous exchange determinations, leaf samples were collected in the central part of the limb and later taken to the Plant Physiology Laboratory to quantify the levels of chlorophyll $a$ and $b$ and carotenoids $\left(\mu \mathrm{g} \mathrm{cm}^{-2}\right.$ ). The chlorophyll extraction was done in $80 \%$ acetone and the spectrophotometric quantification, and the results were expressed in $\mu \mathrm{g} \mathrm{cm}^{-2}$, based on the methodology used by Lima et al. (2015). Together with evaluation of chloroplastidic pigments, the cell membrane damages were evaluated under conditions of saline stress, to identify the percentage of damage in the leaf cell membranes of the West Indian cherry crop, based on the methodology 
used by Lima et al. (2015), the data being expressed as a percentage. For the monitoring of the water relations of the West Indian cherry plants, three fully expanded leaves were collected located in the middle third of each plant, to determine the relative water content in the leaf limb and the water saturation deficit following the methodology used by Lima et al. (2015)

The data were submitted to analysis of variance by the $\mathrm{F}$ test, the means of the $\mathrm{P} / \mathrm{N}$ ratios were compared by the Tukey test $(p<0.05)$ and those related to the interaction between water salinity; the proportions of $\mathrm{P} / \mathrm{N}$ and those related to the isolated effects of water salinity were compared by regression, using the Sisvar

\section{Software version 5.1 (FERREIRA, 2011). \\ Results and Discussion}

According to ANOVA, there was a significant interaction $(p<0.05)$ between water salinity levels and fertilization management for the following variables: chlorophyll a, chlorophyll $\mathrm{b}$ and carotenoids (Table 2). For the variables, $\mathrm{CO}_{2}$ assimilation rate, internal $\mathrm{CO}_{2}$ concentration, instantaneous carboxylation efficiency, stomatal conductance, transpiration, instantaneous water use efficiency and the proportion of cellular damage, was observed a significant influence ( $p<0.05$ ) of levels of irrigation water salinity. For the relative water content and water saturation deficit, no significant difference $(p>0.05)$ was noted in the treatments (Table 2).

Table 2. Summary of the $\mathrm{F}$ test for the variables: relative water content (RWT), water saturation deficit (WSD), CO, assimilation rate (A), $\mathrm{CO}_{2}$ internal concentration (Ci), instantaneous efficiency of carboxylation (EiCi), stomatal conductance (gs), transpiration(E), instantaneous water use efficiency (WiUE), chlorophyll a (Clo a), b (Clo b), carotenoids (carot), \% cell damage (EE) in West Indian cherry plants at 150 days after application of salinity levels.

\begin{tabular}{|c|c|c|c|c|c|c|c|}
\hline \multirow{2}{*}{ SV } & \multirow{2}{*}{ DF } & \multicolumn{6}{|c|}{ Significance of the $\mathrm{F}$ test } \\
\hline & & RWT & WSD & A & $\mathrm{Ci}$ & $\mathrm{EiCi}$ & gs \\
\hline Blokc & 2 & $\mathrm{~ns}$ & $\mathrm{~ns}$ & $*$ & ns & ns & ns \\
\hline Sal & 4 & ns & ns & $*$ & $*$ & $*$ & $*$ \\
\hline VP & 3 & ns & ns & ns & ns & ns & ns \\
\hline Sal $x$ VP & 12 & ns & ns & ns & ns & ns & ns \\
\hline Erro & 38 & 17.349 & 17.349 & 0.4919 & 1636.32 & 0.00005 & 0.00003 \\
\hline CV & & 5.48 & 17.36 & 23.43 & 24.15 & 28.04 & 23.81 \\
\hline \multirow{2}{*}{ FV } & \multirow{2}{*}{ GL } & \multicolumn{6}{|c|}{ Significância do teste 'F' } \\
\hline & & $\mathrm{E}$ & WiUE & Clo a & Clo b & Carot & $\mathrm{EE}$ \\
\hline Bloco & 2 & $*$ & $*$ & ns & ns & $\mathrm{ns}$ & ns \\
\hline Sal & 4 & $*$ & $*$ & ns & $*$ & ns & $*$ \\
\hline Manejo & 3 & ns & ns & ns & ns & ns & ns \\
\hline Sal x Manejo & 12 & ns & ns & $*$ & $*$ & $*$ & ns \\
\hline Erro & 38 & 0.0166 & 1.4039 & 1.1223 & 0.4624 & 0.0601 & 2.8084 \\
\hline $\mathrm{CV}$ & & 21.68 & 23.08 & 18.75 & 17.62 & 21.72 & 16.73 \\
\hline
\end{tabular}

There was an increase in the internal concentration of $\mathrm{CO}_{2}$ ( $\mathrm{Ci}$ ) in the West Indian cherry plants as a function of the increased salinity of the irrigation water (Figure $1 \mathrm{~A}$ ). Increases in $\mathrm{Ci}$ corroborate the observed reduction in $\mathrm{CO}_{2}$ assimilation rate $(\mathrm{A})$, of the order of 0.63 $\mu \mathrm{mol} \mathrm{m} \mathrm{m}^{-2} \mathrm{~s}^{-1}$ for each unit increase of ECW and, consequently, a decrease in the instantaneous efficiency of carboxylation (EiCi) of 0.0055 for each unit increase in ECW (Figure $1 \mathrm{~B}$ and $\mathrm{C}$ ). The rise in $\mathrm{Ci}$ suggests that there was no lack of substrate for the functioning of Ribulose 1.5 Bisphosphate Carboxylase Oxygenase (RuBisCO)
(Machado et al., 2010; Sá et al., 2015). The low EiCi is related to low efficiency of RuBisCO, caused by the intensity of saline stress, or by the low availability of reducing power (NADP and ATP) provided by the photochemical phase, essential for the regeneration of ribulose 1,5 bisphosphate (Hussain et al., 2012; Silva et al., 2014).

In addition to the changes caused by photosynthesis, the increase in water salinity reduced stomatal conductance (gs), transpiration and the instantaneous efficiency of water use in $36,13,37,12$ and $24,49 \%$, respectively, in relation to values obtained in the control treatment (0.6 $\mathrm{dS}^{-1}$ ) (Figures 1D, E and F). 

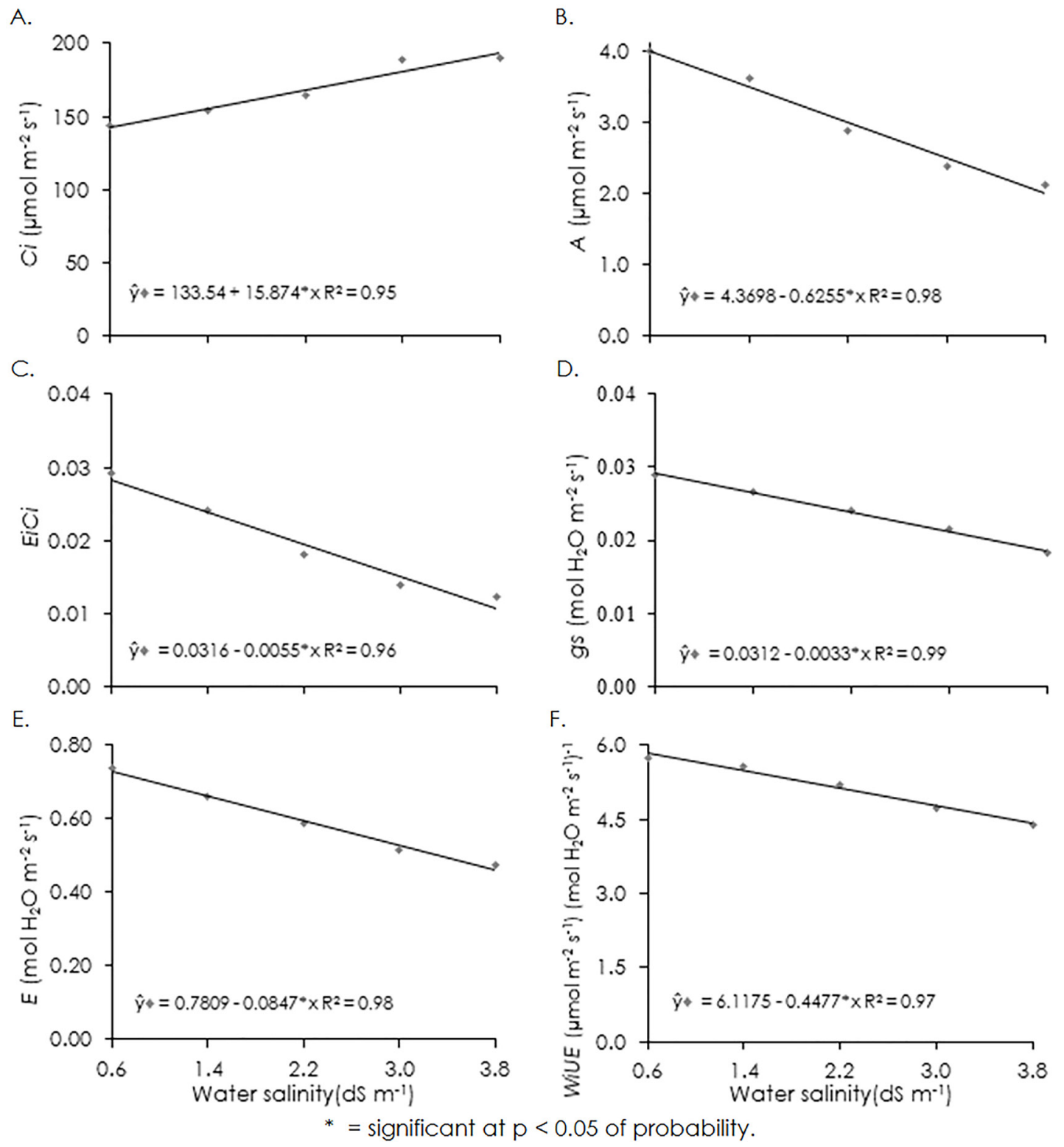

Figure 1. Internal concentration of $\mathrm{CO}_{2}-\mathrm{Ci}(\mathrm{A}), \mathrm{CO}_{2}-\mathrm{A}(\mathrm{B})$ assimilation rate, instantaneous efficiency of carboxylation - EiC (C), stomatal conductance - gs (D), transpiration - E (E), instantaneous efficiency of water use - WiUE (F) of West Indian cherry plants irrigated with saline water and fertilized with nitrogen and phosphorus at 150 days after application of saline levels.

The observed reductions in the activity of gaseous exchange of the West Indian cherry can also be attributed to the effect of saline stress on stomatal activity. Stomata are responsible for regulating all gas exchange and consequently water loss by plants (Suassuna et al., 2015), which promotes the reduction of water potential in cell walls, intercellular spaces, and xylem, allowing difference of potentials, a fact that favors the absorption of water and nutrients via root system. Thus, the reduction of E also reduces the water absorption capacity of the roots, a fact associated to the mechanism of tolerance of the species aiming at the reduction of water absorption and dissolved toxic ions, especially $\mathrm{Na}^{+}$and $\mathrm{Cl}$, therefore reducing the toxicity by ions (Lacerda et al., 2006; Syvertsen \& Garcia-Sanchez, 2014). This result indicates that stomatal factors act in conjunction with those of biochemical order, in the expression of saline stress in West Indian cherry crop.

The increase in water salinity levels significantly reduced chlorophyll a (Figure 2A) and $\mathrm{b}$ (Figure $2 \mathrm{~B}$ ), regardless of the $\mathrm{N}$ and/or $\mathrm{P}$ dose applied, however, the highest levels were 
obtained in the plants fertilized with 100:140\% P/N. (Figure 2A and B). Considering these elements, the decrease in chlorophyll levels $a$ and b (Figure $2 \mathrm{~A}$ and $\mathrm{B}$ ) may be related to the increased activity of chlorophyllase, the enzyme involved in the removal of phytol during the degradation of chlorophyll provided by the stress condition to which the plant was submitted (Silveira et al., 2010).

It can also be observed that (Figure 2B) the quadratic behavior of chlorophyll b fertilizer plants with 140:140\% P/N, obtaining the highest

A.

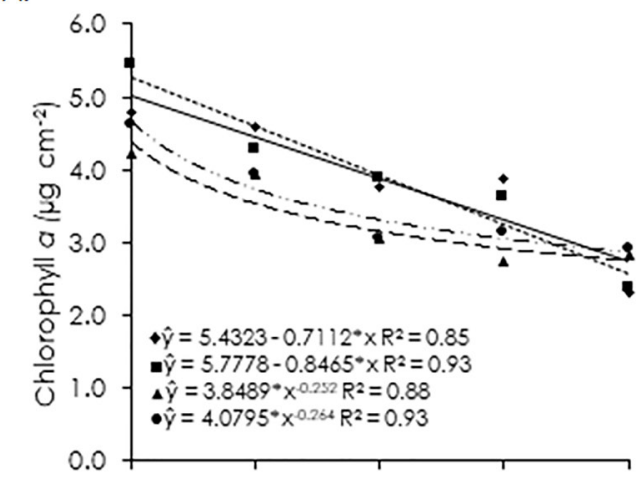

c.

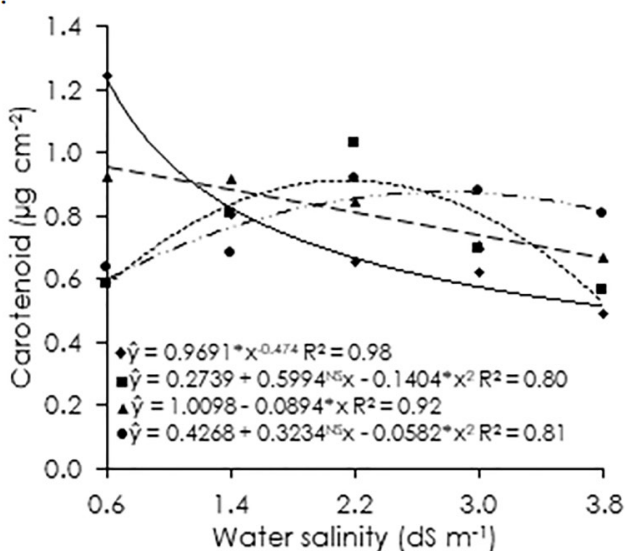

levels under the salinity level of $1.64 \mathrm{dS} \mathrm{m}^{-1}$, being more accentuated above the level of $2.2 \mathrm{dS} \mathrm{m^{-1 }}$ (Figure $2 \mathrm{~B}$ ). The chlorophyll $b$ is an accessory pigment to chlorophyll $a$, since it captures light in an atypical band to chlorophyll a (Silveira et al., 2010), in this way the increase in the chlorophyll b levels is an indication of adaptation of the plants to maintain the photochemical activity under conditions of saline stress. Also, the reduction in chlorophyll biosynthesis can also be an adaptive response to the stress condition, aiming at energy savings and lower light energy uptake to avoid

B.
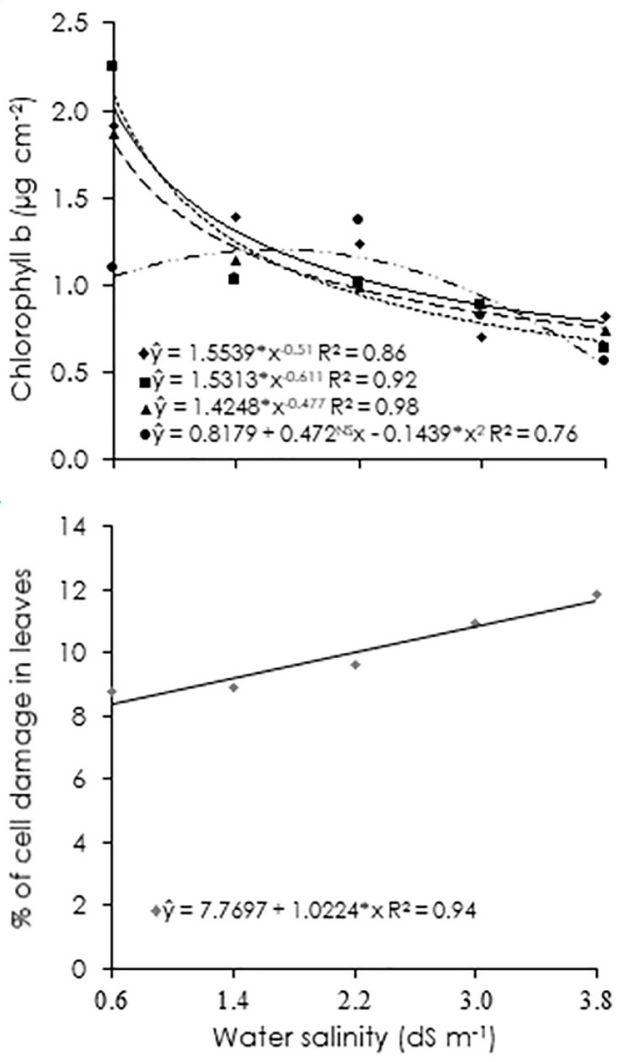

-100:100\% P/N; -100:140\% P/N; $\Delta$ 140:100\% P/N and •140:140\% P/N

** and NS = significant at $P<0.05$ of probability and not significant, respectively.

Figure 2. Levels of chlorophyll a (A), b (B), carotenoid (C) and \% of cell damage in leaves (D) of West Indian cherry plants irrigated with saline water and fertilization with nitrogen and phosphorus doses.

photo-oxidative stress (Silveira et al., 2010).

The highest reductions in carotenoid contents were observed in treatments with $\mathrm{P} / \mathrm{N}$ ratios equal to $100: 100$ and 140:100\%, of the order of 58.5 and $29.5 \%$, respectively, when compared to treatments with the highest ECW $\left(3.8 \mathrm{dS} \mathrm{m}^{-1}\right)$ and the control $\left(0.6 \mathrm{dS} \mathrm{m}^{-1}\right.$ ) (Figure $2 \mathrm{C}$ ). As for the proportions of $\mathrm{P} / \mathrm{N} 100: 140$ and 140:140\%, quadratic behavior for carotenoid contents were observed as a function of the increase in water salinity, with the highest values for the referred variable being observed under ECW levels of 2.13 and $2.78 \mathrm{dS} \mathrm{m}^{-1}$, respectively (Figure $2 \mathrm{C})$. Consequently, the increase of carotenoid contents may be indicative of adaptations of the plant metabolism to minimize the effects of saline stress, which is shown in the treatments with 100:140 and 140:140\% $\mathrm{P} / \mathrm{N}$, where were verified the highest chlorophyll $a$ and b contents (Figures 2A and B). According to Esteves \& Suzuki (2008) 
and Falk \& Munné-Bosch (2010), carotenoids act as antioxidant agents, regulating the activity of enzymes and endo-proteinases, protecting the lipid membranes of the chlorophyll molecule from oxidative stress caused by saline stress.

The increase in salinity of irrigation water increased the percentage of damages in the leaf cells of the West Indian cherry plants, showing a $1.02 \%$ increase in cell damage for each unit increase in the salinity of the irrigation water, resulting in a $39 \%$ rise in cellular damage to plants cultivated under the highest ECW level (3.8 $\mathrm{dS} \mathrm{m}^{-1}$ ) in relation to the plants submitted to the lowest level (0.6 dS $\mathrm{m}^{-1}$ ) saline water (Figure 2D). The increase in the percentage of damages in the foliar cells is indicative of the strong performance of the saline stress on the plants of West Indian cherry, since this reduction corroborates with the decline of the chloroplastidic pigments.

\section{Conclusions}

Irrigation with saline water of up to 3.8 $\mathrm{dS} \mathrm{m}^{-1}$ did not affect the water status of the West Indian cherry plants.

The high salinity of irrigation water reduces gaseous exchange activity and increases the percentage of damage in the leaf cells of West Indian cherry plants.

The $40 \%$ increase over recommended dose of nitrogen increases the synthesis of chlorophyll b and carotenoids in the West Indian cherry plant when irrigated with saline water of up to $2.2 \mathrm{dS} \mathrm{m}^{-1}$.

\section{Acknowledgments}

Authors thank CNPq and CAPES for the grant of scholarships and the INCTSal for funding assistance.

\section{References}

Adriano, E., Leonel, S., Evangelista, R.M. 2011. Qualidade de fruto da aceroleira cv. Olivier em dois estádios de maturação. Revista Brasileira Fruticultura Especial: 541-545.

Ayers, R.S., Westcot, D.W. 1999. Qualidade da água na agricultura. 2.ed. UFPB, Campina Grande, Brasil. 153p. (Estudos FAO: Irrigação e Drenagem, 29).

EMBRAPA - Empresa Brasileira de Pesquisa Agropecuária. Manual de análises químicas de solos, plantas e fertilizantes. Brasília, DF: Embrapa
Solos, 2009. $627 \mathrm{p}$.

Epstein, E., Bloom, A.J. 2006. Nutrição mineral de plantas: Princípios e perspectivas. 2.ed. Planta, Londrina, Brasil. 403 p.

Esashika, T., Oliveira, L.A., Moreira, F.W. 2013. Resposta da aceroleira a adubação orgânica, química e foliar num Latossolo da Amazônia Central. Revista de Ciências Agrárias 36: 399-410.

Esteves, B.S., Suzuki, M.S. 2008. Efeito da salinidade sobre as plantas. Oecologia Brasiliensis 12: 662679.

Ferreira, D.F. 2011. Sisvar: A computer statistical analysis system. Ciência e Agrotecnologia 35: 1039-1042.

Hussain, S., Luro, F., Costantino, G., Ollitrault, P., Morillon, R. 2012. Physiological analysis of salt stress behavior of citrus species and genera: Low chloride accumulation as an indicator of salt tolerance. South African Journal of Botany 81: 103-112.

Lacerda, C.F., Morais, H.M.M., Prisco, J.T., Gomes Filho, E., Bezerra, M.A. 2006. Interação entre salinidade e fósforo em plantas de sorgo forrageiro. Revista Ciências Agronômica 37: 258263.

Lima, G.S., Gheyi, H.R., Nobre, R.G., Soares, L.A.A., Xavier, D.A., Santos Junior, J.A. 2015. Water relations and gas exchange in castor bean irrigated with saline water of distinct cationic nature. African Journal of Agricultural Research 10: 1581-1594.

Machado, D.F.S.P., Machado, E.C., Machado, R.S., Ribeiro, R.V. 2010. Efeito da baixa temperatura noturna e do porta-enxerto na variação diurna das trocas gasosas e na atividade fotoquímica de laranjeira 'Valência'. Revista Brasileira de Fruticultura 32: 351-359.

Medeiros, J.F., Lisboa, R.A., Oliveira, M., Silva Júnior, M.J., Alves, L.P. 2003. Caracterização das águas subterrâneas usadas para irrigação na área produtora de melão da Chapada do Apodi. Revista Brasileira de Engenharia Agrícola e Ambiental 7: 469-472.

Mesquita, E.F., Sá, F.V.S., Bertino, A.M.P., Cavalcante, L.F., Paiva, E.P., Ferreira, N.M. 2015. Effect of soil conditioners on the chemical attributes of a saline-sodic soil and on the initial growth of the castor bean plant. Semina: Ciências Agrárias 36: 2527-2538.

Munns, R., Tester, M. 2008. Mechanism of salinity tolerance. Annual Review of Plant Biology 59: 651-681.

Musser, R.S. 1995. Tratos culturais na cultura da 
acerola. In: SÃO JOSÉ, A. R., ALVES, R. E. (ed.). Acerola no Brasil: Produção e mercado. Vitória da Conquista: DFZ/UESB. p. 47-52.

Ribeiro, P.H.P., Gheyi, H.R., Uyeda, C.A., Teixeira, M.B., Soares, F.A.L., Dias, N.S. 2016. Taxa de crescimento e produção de girassol irrigado com água salina sob doses de nitrogênio. Irriga Especial Grandes Culturas: 233-247.

Sá, F.V.S., Brito, M.E.B., Silva, L.A., Moreira, R.C.L., Fernandes, P.D., Figueiredo, L.C. 2015. Fisiologia da percepção do estresse salino em híbridos de tangerineira - Sunki Comum sob solução hidropônica salinizada. Comunicata Scientiae 6: 463-470.

Silva, L.A.S., Brito, M.E.B., Sá, F.V.S., Moreira, R.C.L., Soares Filho, W.S., Fernandes, P.D. 2014. Mecanismos fisiológicos em híbridos de citros sob estresse salino em cultivo hidropônico. Revista Brasileira de Engenharia Agrícola e Ambiental 18: S1-S7.

Silveira, J.A.G., Silva, S.L.F., Silva, E.N., Viégas, R.A. 2010. Mecanismos biomoleculares envolvidos com a resistência ao estresse salino em plantas. In: Gheyi, H.R., Dias, N.S., Lacerda, C.F (ed.). Manejo da salinidade na agricultura irrigada: estudos básicos e aplicados. Fortaleza: INCTSal, p. 171-180.

Sousa, A.E.C., Lacerda, C.F., Gheyi, H.R., Soares, F.A.L., Uyeda, C.A. 2012. Teores de nutrientes foliares e respostas fisiológicas em pinhão manso submetido a estresse salino e adubação fosfatada. Revista Caatinga 25: 144-152.

Souza, K.S., Oliveira, F.A., Guedes Filho, D.H., Brito Neto, J.F. 2009. Avaliação dos componentes de produção da mamoneira em função de doses de calcário e fósforo. Revista Caatinga 22: 116 122.

Suassuna, J.F., Fernandes, P.D., Brito, K.S.A., Nascimento, R., Melo, A.S., Brito, M.E.B. 2014. Trocas gasosas e componentes de crescimento em portaenxertos de citros submetidos à restrição hídrica. Irriga 19: 464-477.

Syvertsen, J.P., Garcia-Sanchez, F. 2014. Multiple abiotic stresses occurring with salinity stress in citrus. Environmental and Experimental Botany 103 128-137. 